\title{
Folklore Firstfruits from Lesbos
}

\author{
W. H. D. Rouse M. A.
}

To cite this article: W. H. D. Rouse M. A. (1896) Folklore Firstfruits from Lesbos, Folklore, 7:2, 142-159, DOI: $10.1080 / 0015587 X .1896 .9720350$

To link to this article: http://dx.doi.org/10.1080/0015587X.1896.9720350

曲 Published online: 14 Feb 2012.

6 Submit your article to this journal $2 \pi$

Q View related articles $\triangle$ 
The third and last stage of the Greek is that which remains to us in Boissonade's Anecdoton. In it new matter, like the attack on the iconoclasts, was added; and the $A$ pology of $\Lambda$ ristides lost in it some of the authentic touches which the Armenian representative of the earlier stage still echoed. The Christian Arabic is a version of this fully developed Greck form. So according to Zotenberg and Kuhn is the Ethiopic; though I do not myself feel sure that the Ethiopic will not be fuund to represent an earlier stage of the Greek. It is possible also that some of the Latin texts may prescrve the older Greck forms. With a view to recovering the Aristides Apology in an authentic form, the Ethiopic and Latin texts of the story should be examined; and scarch made for the lost Syriac form so imperfectly represented by the Armenian. It is even certain that the $\Lambda$ rmenian text, as it survives to us in $\Lambda$ rakhel's poem and in the Menologia, has becn mutilated. For in the so-called Gcography of Vartan, a work of about A.D. 1300, the Indian city of Sinavathan is mentioned as the seat of the kings of India, where $A$ bener and Jovasaph dwelt. But the cxisting Armenian text has lost this detail.

\section{FOLKLORE FIRSTFRUITS FROMI LESBOS.}

bY W. II. D. ROUSE, M.A.

(Read at Mecting of 17 th Deccmber, 1895.)

The following notes were collected, partly from my own observation and questioning of mulctcers and all sorts of odd pcople, partly from Mr. Stavros, schoolmaster of Kalloni, in Lesbos. I have to express my warm thanks to Mr. IV. R. Paton for constant help while in the island. What I 
have to give is but a little out of much, verily firstfruits; enough to show that anyone who could stay long in the place, and really get to know the natives, would get a book ful of harvestings without difficulty. A few further items but not many, are given in a little book of Lesbian tales, by Gcorgcakis (Paris, Maisonneuve).

On the evening of our arrival at Eresos, it so happened that our host was bitten by a large wasp. Far be, it from me to wish ill to any man, except the enemies of England; but if it was fated that our host should be bitten by a wasp, $1 \mathrm{am}$ glad that this befel on that very day. For no sooner had he sat down to drink his evening mastich, than up came an old man, the gardener, and proceeded to cure it. After a little coaxing he was persuaded to tell his charm, and here it is.

(1.) Charm to cure wasp-sting. - $\pi \hat{\imath} \theta_{\iota}-\tilde{\epsilon} \lambda \epsilon-\hat{\eta} \lambda \epsilon-a ̈ y p a$, spit four times on the place; do this thrice, and wind up with $\pi i \theta_{l}$. ( $\pi i \theta_{l}$, "drink," is the old imperative, not now used in common spech. What the other words mean is not clear; perhaps äypa means "catch.")

Two more charms the old man told.

(2.) Charm for a horse that has swallowed lceches.(This takes effect at a distance.) Take a reed and say:

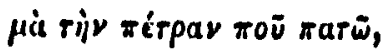

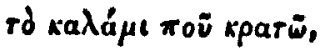

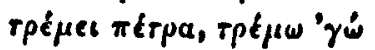

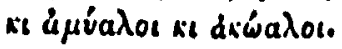

\footnotetext{
"By this stone on which I sland, By the reed that's in my hand, Quakes the stone, and I quake too, And you creatures without bone, Drainless creaturcs, so do you l"
}

Blow three times through the reed towards the sun. 
(3.) Charm against insects.-Take a black knife; in the evening stick it in the spot where they come, and say:

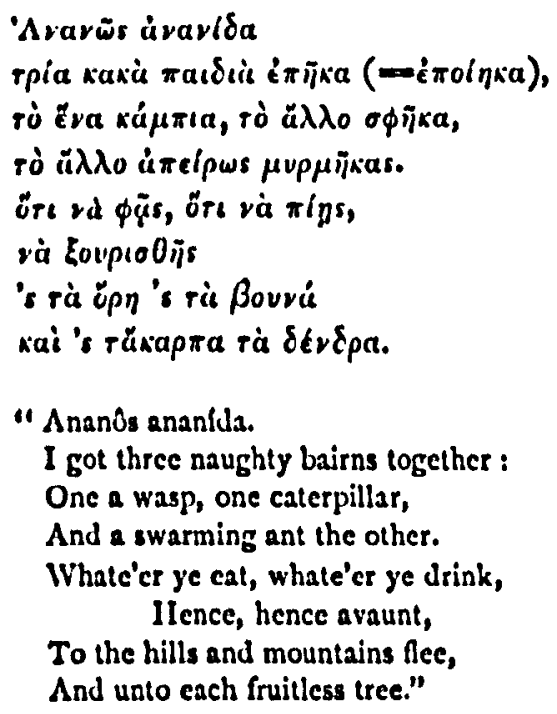

Leave the knife there till morning; then pull it out, and off they go.

When he had finished these charms, the old man took a glass of water, and bade me drink; he then took a sip himself out of the same glass, and, with a wave of the hand,

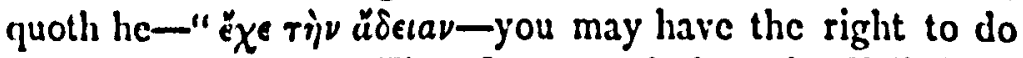
them," he left us. Thus I appear before the Folk-Lore Socicty as a wizard, duly ordained by a " sacrificial feast," and (shall I say?) in right of diabolic succession.

I add one more charm.

(4.) Love Charm. - $\Lambda$ t the site of ancient Arisba, near Kalloni, the girls go to an $\dot{\xi} \xi \omega k \lambda \dot{\eta} \sigma$, or loncly shrinc, of St. Mary, on her holy day, and sing:-

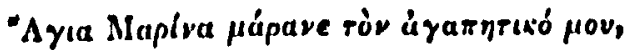

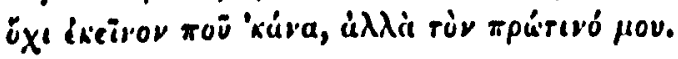

"St. Mary, make to pine with love my darling, not that 
one whom I made, but my first." Perhaps there is a reference to some magic figure.

The Key-and-Bible Charm is also used for finding a thief; it is done by two old women, where three ways meet.

The Nereids are universally believed in. I had much the same account in all parts of the island. The men at first laughed, and said there were no such things; but when I told them that we had Nereids in England, only they were little folk with tall, peaked hats, they took heart, and con. . fessed that, though they had never seen one, people did say, and so forth. They are described as very beautiful women, with black hair, tall, and clad in white; a beautiful girl is often called a "Nereid," while an ugly hag is called a "Fate." They meet men at night, and do them damage by taking away sight, or hearing, or the use of some limb. The old gardener who gave me the charms was deaf. Once when he was keeping his flock on the mountains, he heard a great noise as of bells, and ever since he has been deaf. There is a Nercid in the whirlwind. To keep them off, make a circle round you with a black-handled knife.

Marriage.-Whien a man marries, his friends take him to the house, put him on a large dish, and change his clothes. The girls change the clothes of the bride. The lads tic round the groom a kerchief with a lock in it, to prevent an enemy from rendering him impotent; which he could otherwise do, in the church, by cursing him while the priest pronounced the "blessing." On the wedding night, the groom puts a coin under his pillow, which is the perquisite of the woman who made the bed, as the "price of virginity." On the day after, they take the groom to an $\dot{\xi} \xi_{\omega \kappa} \lambda \dot{\eta} \sigma \iota$, and rub his hands and face with nettles.

Birth.-The priest is called in to read over the babe. Three days after, in the evening, friends and relatives assemble. They throw water and salt in a basin, bathe the child, then drop into it coins for the midwife. On that day fate writes the child's destiny on its forehead; the 
joints of the baby's skull, not yet closed, are the writing. They make a feast, and leave the remains on the table all night for the Three Fates.

Burial.-The priest takes a taper, makes the sign of the cross, and lays the taper on the dead man's mouth; clse he would become a vampire.

Building of Wouses. - When a house is built, sacrifice is made of a fowl, or something clsc. When it is done, they crect two poles with a crosspiece, and all the friends bring gifts-shawl, kerchicf, what they will-and hang upon it.

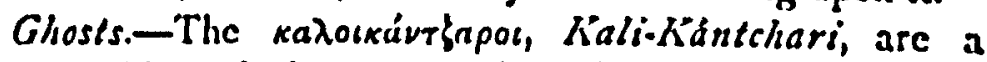
peculiar kind of ghost or goblin which appear only at the Epiphany. To kecp them away, the women rub the walls of a house with ashes, repeating some lines of which my

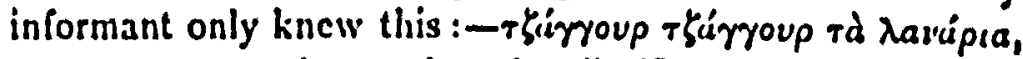
"twang twang the wool-carders." (Sce also Georgeakis op. cit.)

Times and Scasons: May 1.-The people make garlands of flowers and nettles, with garlic or onions, and hang them over the door. I saw these withered wreaths in all parts of the island five months later. They take a garlic, a vine-sprout, and some wine, and cat it before they hear the donkey bray on that day.

Elias' Day: Yuly 2r.-They sacrifice a shecp on the lill where is a church of the proplict Elias.

New Ycar's Eze.-Girls throw holly in the firc, and divine by its crackling about their future husbands, and all matters of interest, whether the mare will have a foal, or the like.

On New Year's Day the people go out carly in the

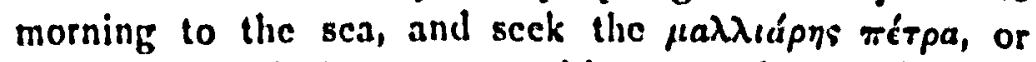
"woolly stone," i.e. a stone with scaweed upon it; this they kecp in their houscs. Those who wish to be beloved break a pomegranate upon it, because the pomegranate means faithfulness, and the stone means steadfastness, as it must lie long in one place for scaweed to grow on it. 
- Platk I.

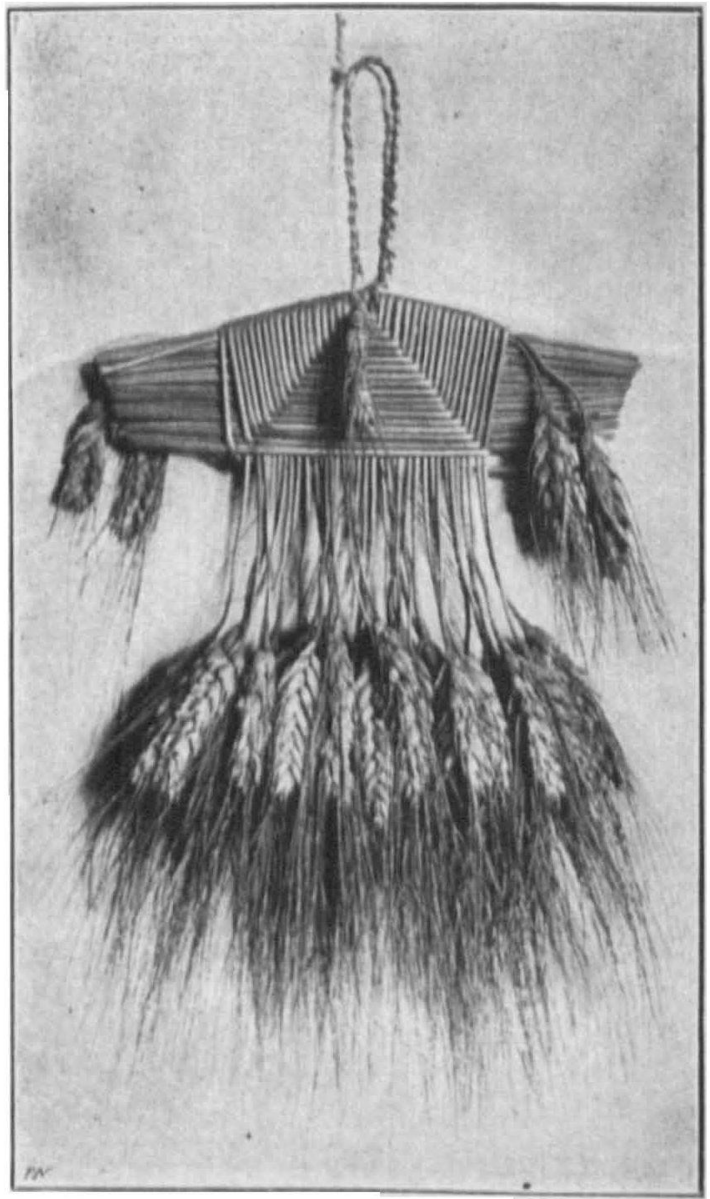

PSATHA ( $P$ CORN-BABY) FROM LESBOS. 
Harvest. - When the corn begins to grow, husband and wife go to opposite sides of the field, and says she to him,

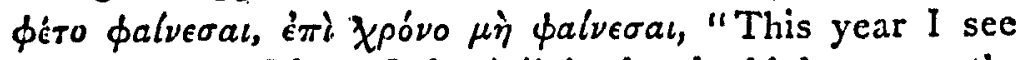
you, next year I hope I shan't," i.e. for the high corn or the heaps of sheaves.

The first ears are plaited into a curious shape; they call

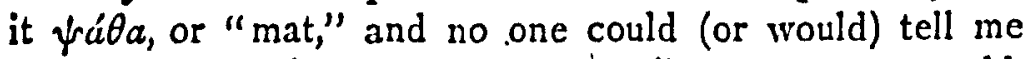
any more about it. But its shape strikes me as very odd, and it bears no small resemblance, to a human figure in a cloak, with arms outstretched. I send a specimen herewith, which is to go to the Society's museum. In some of them the neck is adorned with a necklace of beads. I saw these in all parts of Lesbos, always with the same shape; and also on the mainland of Greece, where they called it

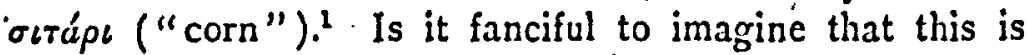
really a corn-baby? It ought, however, to be made of the last sheaf, not the first.

Sacrifice: Gilding the Horns of Victim.-Mr. Stavros saw this done within' the last five years at an $\dot{\xi} \xi \omega \kappa \lambda \eta^{\prime} \sigma$. They often kill a victim, cook it, and distribute the flesh at one of these "out-churches," or deserted shrines. In Ayassos, at the great Panegyris, or religious assembly, I saw the meat in the butchers' stalls adorned with large patches of gold leaf, which may perhaps be also a reminiscence of the classical custom.

-Disease.-St. John is the favourite saint for those who suffer from fever, "because when his head was cut off, he trembled all over."

Mothers with sick children and sick folks generally go to some monastery and stay there for days, the priest saying prayers over them every day. If there they get no better, off they go to another. The monasteries have spare rooms for them; and sometimes, as at the holy place

1 Mate I. The Society is indelsted for the pholograph to Dr. Oscar Clark. A similar object, from Syria, may be seen in the Biblical Muscum, Sergeants' Inn, Flect Street. 


\section{I48 Folklore Firstfruits from Lesbos.}

of Mandamádos, the church is surrounded by buildings like a college quadrangle, simply for sick folk and pilgrims. On the great festivals they actually sleep in the church, just as the ancients slept in the temple of Esculapius. At Ayassos I saw this: the side aisles were crammed with visitors "incubating"; their bedding was piled in heaps on the top of the carved stalls of the nave. They cook in the church, and make their home there while the feast lasts. Miraculous cures are supposed to take place on these occasions. The Bishop told us of two miracles in which he was privileged to be the humble instrument. A church once took fire, and no water was to be had, so he put it out by means of water melons, "by the help of God." On another occasion, if I understood him aright, he put out a fire with one blanket.

The Evil Eye.-Here, as in all parts of the Greek world, the Evil Eye is believed in. Skulls of oxen or other horned creatures are hung on sticks or trees to avert it from the crops and the fruit. I saw one tree which bore the model of a bullock's head, coloured to imitate life; of this I have a photograph. If a man yawns much, he is supposed to have been overlooked. If you admire a child, the mother spits three times in her bosom, as did Polyphemus in Theo-

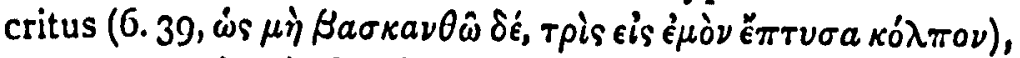

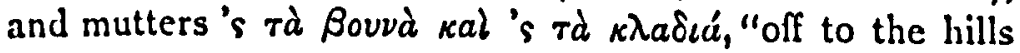
and the branches," which reminds us of the third charm given in this paper.

A $\beta a \sigma \kappa a \mu \mu$ ves is fumigated with incense; in the censer they burn flowers that have been blest in church by the priest, and put cloves in the name, by whose jumping or hopping they divine who did it. This cure was wrought on me by an old dame of Mytilene. I had taken her photograph in the afternoon, and in the evening I had a headache. "Poor boy!" she said, "he was overlooked; everybody stared at him as he was doing the photograph." She passed the censer three times round my head, and 
thrice waved it before me in the sign of the cross, muttering :-

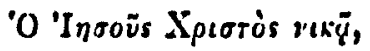

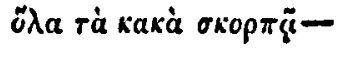 \\ "Jesus Christ conquers, \\ All nischiefs he scatters."
}

Finally, she dropt in an ivy twig, which popped and crackled. "Now he'll get well," she said. So I did; the headache was quite gone next day.

Sacred Places, Holy Trees and Wells.-There are some interesting sanctuaries in the island, at which are held famous festivals; the chief are Ayássos and Mandamádos. Of these I could a tale unfold; but it would not bear upon folklore, so I leave it unsaid in this place. But all over the island, almost in every square mile, are endless $\dot{\xi} \xi \omega \kappa \lambda \dot{\eta} \sigma \iota a$, or country shrines, many ruined, but most still frequented on the day of their saint, when the people come to worship and make offerings. I cannot help thinking that these may often mark the spots where in ancient times a bit of the farm land was left fallow for Pan and the Nymphs. Some few

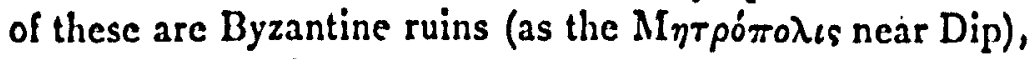
some are roofed and complete, many mere enclosures. Some have a sacred well in or near them, as that of St. Paul, near Eresos.' Here hang the rags of the worshippers, most of them fastened first to sticks and then thrust into the cracks between the stones; one was fastened to an iron nail; a few are hung to the twigs of agnus castus bushes which grow outside the walls. This plant appears to be a favourite in Lesbos for the purpose. It was sacred in ancient times; and it was associated with IIera in Samos (ef Paus. iii. 14.7, vii 4.4, viii 23.5, and the art. Agnos in Pauly).

vol. vis.

I Of these I have photozapls. 
(2.) There is another "sacred spring" near Eresos; only a hollow in the rock, where water is seen sometimes.

(3.) Near Mesotopos there is a chapel; and beside it is another sacred tree, ${ }^{1}$ this time a tree whose name was given variously as $\pi \epsilon \tau \rho a \mu l \tau \iota a$ or $\tau \epsilon \tau \rho a \mu \eta \theta_{\iota a}$. It had a funny little red pod of irregular shape, but what its botanical name is I know not. There were women's embroideries and whole garments of children on this tree, besides rags.

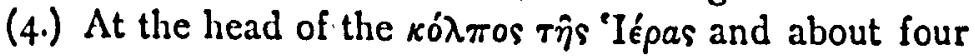
hours from Mytilene, at "Lap Mill," are two shrines, both shadowed by trees, and each sacred to a separate St. George: one Christian and one Moslem. The Moslems revere a St. George of their own, whose tomb I have seen at Damascus; but in default of the right one, a Moslem worships the St. George of the Christians. However, here he can take his choice. The Moslem shrine faced the opposite way to the Christian, and had wax candles in it; the Christian shrine had rags and dresses as usual in it and hung upon an agnus castus outside.

(5.) By the waters of the gulf, an hour. or so from Mytilenc, is another little chapel, ${ }^{1}$ upon the very shore, "Arıos Eapáñs or St. Healer. I could see no spring, but there were (and still are) hot springs in this gulf; and I make no doubt this is an ancient site. Esculapius was the great god of Mytilene in olden days. By the roadside, above this chapel, are sacred trees with rags as usual; one was an olive. The chapel is invisible from the road, which is some twenty feet higher.

(6.) St. Eudokimos, a shrine in the town of Mytilene, where nearly all the votive offerings are onions fastened to a tree, the same kind of tree as No. 3 , by sick folks.

(7.) In another shrine, which I have not seen, women. leave as offerings the wooden frame on which they spin and wind thread. 
Plate Ia.

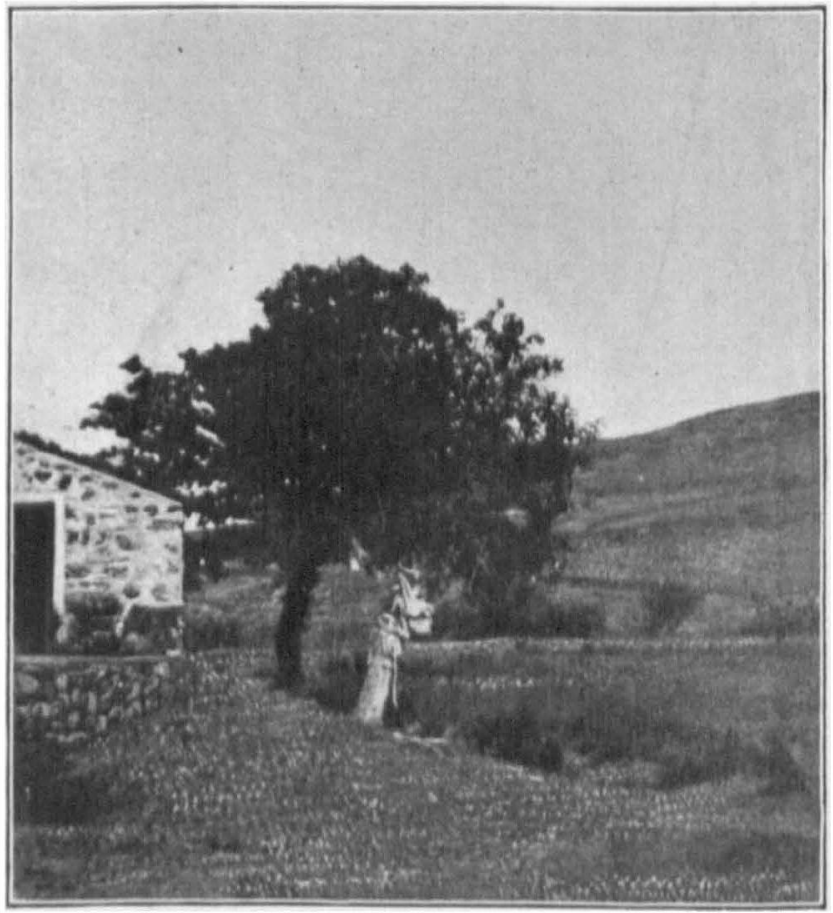

SACRED TREE AT MESOTOPOS.

[Two trees are shown, of which the nearer (the sacred tree) has its trunk wrapt about with rags and garments. The name of the tree I have now ascertained to be depapirua. To the left is the chapel. W. H. D. R., October, 1896.] 
(8.) $\mathrm{A}$ very curious shrine (Moslem) is one at the very top of the Citadel of Mytilene, the tomb of a dervish. They keep sheepskins here, and the worshippers wrap. themselves in these when they pray. This reminds us of the $\Delta i o s \kappa(\omega i \delta ı v$. It is possible that the Moslems have here preserved a bit of Greek ritual.

(9.) In the street of Eresos is a tiny shrine; a cupboard, which being opened, discloses a gaudy but tattered picture of St. George and the Dragon, some other pictures, and an oblong bean-shaped stone, about 12 inches long; black with grease. This they stick candles on, and I think it may be a Baitudos.

Animals, Birds, \&c. :-For the Ass, see under May 3.

When the $j a y$ appears, something must be drunk before its voice is heard, else the breath will have an evil smell. The same is done on seeing the cuckoo for the first time; my informant did not know why.

Lesbos is a good place for stories. Mr. Paton has already gathered a good many there; and I venture to hope that the Society will support his design of making a collection of Island Stories: little or nothing has been hitherto done for this part of the Greek world. Some excellent stories were told us while I was there, and I subjoin three of them. The third (a version of the Forty Thieves) was written down by Mr. Paton; and in the others he gave me much hclp, for which I thank him here.

\section{(1.) The Snake-Cypress.}

Once upon a time there was a man and wife, who had an only son, and they sent him far away across the seas to learn music. In due time, he came back, and everybody agreed that he played to a marvel; but his mother was angry with him, because he was in love with some girl she did not like. "All right," quoth he, "give me some moncy 


\section{Folklore Firstfruits from Lesbos.}

and I'll be off." So she gave him some money, and sent him away to keep him out of mischief.

So off he went; and on the way what should he meet but a huge snake. The boy was scared out of his wits. Says the snake: "Play to me I and I'll dance." So terrified was the boy, that he did as he was bid; and the snake danced to him. He danced till he had enough, and then says he: "Thank you," says he, "and now come along with with me." So the lad went with him to his cave, and there showed him heaps upon heaps of treasures. What pearls I what gold pieces! what diamonds! Says he to the lad: "Take your choice, whatever you like." So the lad did. "Now," quoth the snake, "you must swear that when you are married, you will invite me to the feast, and call me your brother. If you don't, I shall die; and if I die, this is what you must do. You must take my bones and bury them in the earth, outside your house; from that spot a cypress will grow up, all in one night. And in the evening when you sit under it with your bride, to drink coffee, you must have three cups of coffee made ; one cup leave behind, and the cypress tree will come down and drink it. And if anybody asks you what this cup means, you must propound this riddle ; they are to stake their fortunes on it, and shall have three guesses. What tree is this? The answer is, a Snake-cypress. As long as none guess it, I am safe; but once guessed, the tree will fall to the ground and die."

So the boy returned home, and a wife was found for him. Says he to his mother: "Mother, I want to bring a guest to the betrothal feast." "Who is it?" she asked. Says he: "My brother." "Brother indeed!" says she, "are you mad? you are my only child, as you know well enough, and brother you have none !" So he did not invite his friend the snake to the betrothal. The snake met him, and reproached him, saying again: "If you don't have me at your wedding, I shall die." But he was persuaded not to invite him to the wedding, and the snake died. 
Then the lad took the snake's bones and buried them in the garden near his house. In the night, up shot a tall cypress tree, to the amazement of every one. That evening he sat under the tree with his bride, and three cups of coffee were brought for the two. This happened again and again, and at last the wife grew jealous. "There must be some woman hidden here," thought she, "my husband's lover; and she it is drinks the third cup of coffee." So at the last she could bear it no longer, and taxed her husband with unfaithfulness. He protested, and for a long time held out; but at last things became so bad between them that he told her the whole story; how the cypress grew from the bones of his brother, the snake, and how the tree used to come down when they were gone, and drink the coffee; and told her the riddle. But it so happened that while he told her, his serving-man was close by, and heard it all.

Now many people used to come and try to guess his riddle; they would stake their all upon it, make their three guesses, and fail, so that in time he grew very rich in this way. When the servant overheard the secret, he came and asked for his wages, saying that he wished to leave his service. The master took him to a coffer full of gold and jewels, bidding him take what he wanted. So the man took all he wanted, and went off. After a time back he came, disguised as a merchant, and when he saw the three cups of coffce he asked what it all meant. "Tell me my riddle first," quoth the master, "and then l'll tell you. What's this tree?" "Apple-tree.". "No," says he. "Pear-tree then." "No," said he again. Pretending to think, the man at last replied: "It is a Snakc-cypress!" No sooner had the word been spoken, than down fell the trce, snapt off as clean as if it had been cut through by the axe.

The man was distressed and angry. How could he have guessed it? There was only one way, his wife must have 


\section{I54 Folklore Firstfruits from Lesbos.}

betrayed him, and told the answer. So he said to his wife: "Here, this man is your husband, not I. Keep him I will stay here no longer." And off he went.

On the way he met an old woman sitting by the roadside. "Good day, mother," says he. "Good-day to ye, my son," says the woman, "and where are you going?" "I don't know," he says, and told her what had happened. So she says, "I'll give you another riddle to ask them. Say, Does the sun rise in the east or in the west? They will all say in the east, then I'll make it rise in the west." So he returned and asked his riddle to all the people: "Does the sun rise in the east or in the west?" "In the east, of course," they said. "No," says he. "All right, we'll see to-morrow morning." Morning came; all the people stood gazing towards the east, and watching for the sun; no sun came. They saw the sky grow light, they felt their backs hot; after an hour or two, somebody thought of turning round; lo and behold! there was the sun blazing away in the west, as the old woman had said. The man went back to his wife, and they lived happily ever after.

\section{(2.) The Three Thieves.}

Once there was a good man whose fortune was in the sun. ${ }^{1}$ He went out on the hill, and saw three thieves who had killed a goat. They told him to cook it. Well, as they say, "a thief among thieves, and a liar among liars;" 2 so he nodded without speaking, and did as he was bid. They asked him his name, and he said 'Amatós - "Mr. Self." When he had cooked the goat, he beat the three thieves soundly with the spit, and they ran off

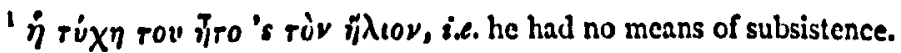

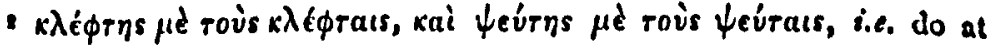
Rome as the Romans do. 
howling. People asked them who did it? " "Self!" said they, and got laughed at for their pains.

[I give this story, because the motive is like that of the story where Odysseus blinds the Cyclops, and says his name is "No-man."]

\section{(3.) The Forty Thieves.}

Once upon a time there was a poor man who had three daughters. He made his living by gathering sticks, but it was wretched work, and his life was in the sun. One day he saw a donkey and thought what a help it would be to him, and how many more sticks he could bring from the hill if he had it. When he got home, he told his daughters and they said: "Sell us and buy it." But he said: "Better to suffer anything than to sell my daughters." Next day, coming back with his load of sticks, he sat down to rest, and at his feet he saw three dollars, and he went straight off and bought the donkey with this. On the morrow he started off in great glee with the donkey to gather sticks, and on the road he heard a noise like thunder, which secmed to come nearer and nearer to him. He was in great fear and hid himself, and from his hiding place saw 40 ogres with skulls on their backs. They stopped before a wall (pákтos); and one said: "Ach Karakiz," and im. mediately the wall opened and they all went in. He waited to see what would happen; and after a little, they came out, and the last said: "Kapla Karakiz," and the wall shut. The old man went up to the rock and called: "Ach Karakiz." At once the rock opened, and going in, he found himself in a cave with 40 heaps of gold, and pearls, and diamonds. Taking a little from each heap he loaded the donkey with as much as it could bear, and once outside said: "Kapla Karakiz," and went home with his load and told his daughters all about his good luck.

Next day he came back, and when the ogres had gone, 
went in, and again took a little from each heap and loaded his donkey and went home.

On the third day he went back again, but this time took all from one heap; and when the ogres saw their loss they said : "We must set a watch to catch the thief," and left one of their number inside.

On the fourth day he went again and hid, to see the ogres go in and out; and when they came out he counted them, and there were only 39 ; but when he counted them backwards there were 40, and he said to himself : "It is all right," and went into the cave. The ogre was there watching for him, and fell upon him and slew him, and cutting him into 40 pieces, put a piece on each heap. When the other ogres came, their brother ran to meet them, and said : "I've caught the thief," and showed them the 40 pieces. "But didn't you ask his name first, and what village he lives in?" said they, and fell into a rage with him.

They resolved to dress up as Jews and to go round the villages selling rings and bracelets. It so chanced that one came to the old man's village and to his house. The eldest daughter heard him crying: "Rings to sell, bracelets to sell," and ran down. One bracelet pleased her very much; but she had no money to buy it with. So she went and brought the biggest diamond of all, and offered it in payment. Then the ogre knew who the thief was, and marked the door with paint, and went back and told the others.

Then they resolved that he should sew them up in bales, and pretend he was a merchant and go to seek shelter at that house. This was done. He came to the house, and begged to be allowed to leave his merchandise in the courtyard, and lie there himself that night. The three girls agreed, and took him upstairs and prepared dinner for him. The cldest cooked, the second served, the youngest kept the oven alight. They gave him a splendid dinner and lots of good wine, so that he grew drunk and fell asleep. The youngest daughter was kceping up a big fire in the 
oven, and when her fuel was done put in one after another the merchants' bales, and finally the merchant himself. So there was an end of the ogres.

The three girls now went on taking as many donkeyloads of treasure as they wished from the cave. They got so rich that they built a big house and bought a vast deal of property. They had for a neighbour a rich and wicked woman; when she saw how rich the three poor girls were become, she grew very anxious and longed to know where all this wealth came from. One day they sent to borrow her corn-measure $(s n i c h)$. Before sending it she rubbed honey on the bottom of it, and when it was returned there was a gold coin sticking to it. She came at once and asked them what they had been measuring. "Only a little corn our uncle sent us." But when she showed them the coin they were obliged to confess and tell her the whole story. She sent off her husband to the rock, and made one of the girls go with him. After he had been taken once or twice by the girl he went one day by himself; but God did not love him, and as he was coming out the rock shut upon him and crushed him. When he did not appear at home he was found by the girl. The neighbour now married a second husband; but he met with the same fate, and so a third. She then went to work to get the girls' husbands into her power, and succeeded so well that they left their wives and, taking all the treasure, went to live with her; and the three girls were as poor as ever.

One day the eldest went to confess her sins; and on the way back she met the devil. He said: "Where are you going? Will you be my servant? I have a beautiful house." "Is it far?" "No, we'll soon be there." She consented; and he took her to a cave-"Ach Karakiz"-and there gave her a leg of rotten meat and told her to cat it before his return. Before he went out, he found out from her all about her sisters and where they lived.

The poor girl could not eat the bone, but hid it in the ashes; 


\section{I58 Folklore Firstfruits from Lesbos.}

and when the accursed returned, he called out: "Bone, bone, where are you?" "In the ashes," said the bone. So he gave the girl a kick, and made her into a broom.

The devil then went off to the girl's house and persuaded the second sister to come on service. As before, he took her to the cave-"Ach Karakiz" - gave her the rotten bone, and left her to eat it. She hid it under the matting. On returning, he called out: "Bone, bone, where are you ?" "Under the matting." So he gave the girl a kick, and turned her into a water-jug.

The next day he went for the third, and told her her sisters wanted to see her. He gave her the bone, and told her if she did not eat it she would be like her sisters, whom he had made into a broom and a water-pitcher. She had brought a kitten with her, and cut the meat up into little bits, and made the kitten finish it. In the evening when the accursed one came home and called: "Bone, bone, where are you?" "In the stomach," said the bone: and he was in such a rage he never thought of asking whose stomach, but at once he burst asunder. Then she went and kicked the broom and water-pitcher; and they turned into her sisters again. The three set off to explore the cave, which had a great many rooms, and there were countless men hung up in punishment. These they freed, after learning their sins. In the darkest room they found three young men, and asked them the reason of their punishment. It was fornication.

When they had set them free, the three youths asked the three girls to marry them; and the girls consented. The two eldest couples were married at once; but the youngest pallikari desired to be betrothed only, and to go home with his bride, and celebrate the wedding at his own home. "But," said the youngest girl, "when you see your mother you will say, ' $O$, mother,' and forget all about me." He assured her he would not, and they started for his home. As they approached the town, he saw his mother a long 
way off, and he said: "Let me go on and speak to her." "No," said the bride, "wait until we come to your house." But he would do it, and ran up to his mother and said : " $O$, mother," and forgot all about his bride. The girl went on alone to the town, and ordered masons to come and build a house. In a month it was finished. She stood on the balcony; and her betrothed passed by, and, looking up, saw a pretty girl who pleased him; but, of course, he did not remember her. He made signs to her, to ask if he might come up; and she nodded her head, and in the evening he came to visit her. She had a tame lion, and she had told him: "When a man comes in, tear him to bits;" and the lion did so. She picked up the bits, put them outside, and went to bed.

In the morning they found the bits, and she was ordered to go to the council to be tried. She refused to come, unless they would send a carriage to fetch her, and strew all the road with velvet rugs. Again the summons came, and again she refused; and so the third time. So the Pasha was obliged to consent. She came beforc him; "Glad to see you, Governor," says she; then she told all her story to everybody in their own tongue. And all the people pitied her, and she was acquitted, and lived alone in happiness ever after. 